\title{
Hazard Identification and Risk of Work Assessment on Street Sweeper in Medan City
}

\author{
Umi Salmah \\ Fakultas Kesehatan Masyarakat Universitas Sumatera Utara, Indonesia \\ umisalmah@usu.ac.id
}

\begin{abstract}
In 2015 Social Security Agency Employment (BPJS) reported that in the first semester reached 50.089 cases of occupational accidents. The work accident can be avoided by knowing and recognizing the potential hazard and risk of work environment the act of controlling can be implemented. The purpose of this research is to identify the hazard and risk of work assessment on street sweeper in Medan City. This qualitative study is snowball sampling with observation and direct interview with 20 informants and then the data is presented with narrative text.

This study finds that there are some risks from 3 routinework stages (sweeping, lifting, and garbage collecting), that is 10 potential hazard sources; 4 physical hazards, 1 chemical hazard, 1 biological hazards, 2 physiological hazards and 2 safety hazards and for the risk assessment, it is identified 6 activities categorized as low category $(60 \%), 2$ activities categorized as moderate $(20 \%), 1$ category categorized as high activity $(10 \%)$ and 1 activity categorized as extreme category $(\mathbf{1 0 \%})$. While from 3non routine-work stages (employees of grass cutter, puddle sweeper, and dust removal) there are 3 sources of hazard and risk assessment with low category.

It can be concluded that the hazard source with low risk (low) in the sense of risk is acceptable, so that we do not need any handle / control, while the potential source of hazard categorized as Moderate, High and Extreme need more control. Dinas kebersihan as the leading sector of the street sweeper in Medan is being expected to make and socialize SOP of work so that they can work well for $\mathrm{K} 3$ efforts.
\end{abstract}

Keywords - Street sweeper, potential hazard, occupational risk

\section{Introduction}

In 2015 Social Security Agency (BPJS) of Employment reported that in the first half it reached 50.089 cases of accidents [1]. Accident prevention efforts can be planned and carried out by knowing the risks of a work so that the prevention and mitigation can be selected through the most appropriate approach. Workplace accidents can be avoided by knowing and recognizing the variety of hazards potential in the work environment as early as possible. Analysis of the accidents and risks is based on recognition or hazard identification in the work environment and the measurement of workplace hazards. The accident scene is a series of events caused by other factors or potential hazards associated with each other [2]. The variety of potential hazards can be eliminated and the risk of accidents that will occur can be avoided. Hazard identification provides a variety of benefits including reducing the chances of accidents, because the hazard identification associated with the causes of accidents. To provide an understanding for all people regarding the potential dangers of the activity of the company so it can increase vigilance in running the company's operations. As the cornerstone well as inputs to determine the strategy of prevention and treatment is appropriate and effective. By knowing the existing hazard, management can determine the scale of priority handling in accordance with the level of risk that the expected results will be more effective [3].

If the hazard can not be eliminated, then the control measures should be implemented to minimize the risk of potential hazards to be accepted by the workers. Based on Undang-undang Republik Indonesia No. 1 of 1970 "Occupational Safety" that all workers are entitled to protection of their safety in doing work for the welfare and increase the production and national productivity [4]. Therefore, in accordance with applicable regulations of each company in which there are workers and the risk of hazards is obliged to provide safety protection. So that to provide appropriate protection for workers begins with the process of identified hazards in the work activity routine or nonroutine performed in the company's workers, for further risk assessment of these hazards.. The results of the risk assessment is needed to create a hazard control program for workers at companies that can minimize health and safety risks that might happen.

HIRARC (Hazard Identification Risk Assessment and Risk Control) is a principal element in Occupational Safety and Health Management Systems work directly related to the Prevention and Control of Hazards [5]. This method is a part of the risk management and directs the implementation of $\mathrm{K} 3$ in 
the company. According to Agwu.M.O in international journals in 2012 "The Effects of Risk Assesment (Hirarc) on Organisational Performance in Selected Contruction Companies in Nigeria" there are linkages among risk assessments (HIRARC) with declining the incidence of accidents [6].

Dinas Kebersihan employs a street sweeper who resolves the waste problem. Dinas Kebersihan established a team in maintaining the cleanliness of the environment to stay clean, healthy and beautiful. This is supported by the regulation from the district head of Medan No.14 of 2014 on the establishment of technical and operational units cleaning services and technical and operational units of garbage bank in Dinas Kebersihan [7]. Technical cleaning services consists of: Session I Medan Operations, Operational Session II Session III Operational Medan. The street sweeper is conducted to sweep the road, sidewalk, street protocols and feeder roads. Based on the initial survey results groups of street sweeper, Melati, showed that the existence of various occupational risk encountered in accordance with applicable regulations of each company in which there are workers and the risk of hazard obliged to provide protection to health and safety, the initial step needs to be done is a Hazard Identification and Risk of Work Assessment on street sweeper.

\section{MATERIALS AND METHODS}

\section{A. Research Approach}

This study used a qualitative approach to explore and understand of individual or group of people ascribed social or humanitarian problems [8] .Determination of informants using nonprobability sampling techniques are porpusive and snowball sampling is that labor groups working in the Melati Session 1,2,3 Operations and consists of 21 districts.

\section{B. Procedures}

The Methods of collecting primary data were obtained from direct observation and free interviews to informants. In qualitative research, the main instrument is the researchers themselves [9]. Resource persons from the interview are workers and the mechanics. The observation is open observation which the existence of an observer known to the subject of the study and the subject provides an opportunity for observers to observe the events that occurred and the subject is aware of the people who observe what subjects [10].

\section{Data Analysis}

The data analysis begins by calculating the risk values obtained from the results of interviews conducted based on standards AS/NZS 4360-2004. According to AS / NZS assessment in the risk assessment that the likelihood and severity. Likelihood indicates how likely the accident occurred, severity indicates how severe the impact of the accident. The value of the likelihood and severity will be used to determine the risk rating [11] . Determination of the likelihood and severity by calculating a risk score using the formula: Risk = likelihood $\mathrm{x}$ severity rating, to obtain risk rating which consists of four categories, the Extreme Risk, High Risk, Moderate Risk, and Low Risk.

\section{RESULT}

From the 20 informants interviewed informants known to the youngest only 26 years old and the oldest 58 years old. Lowest level of education is elementary school (SD) and the highest is the high school (SMA). The Longest length of work is \pm 30 years old and 2yeaized as low. Working time longest at 05.30- 13:00 $\mathrm{pm}$ and the fastest 6:00 to 12:00 pm. The workload of the longest ie $\geq 2 \mathrm{~km}$ and the shortest $\pm 1 \mathrm{~km}$. 
TABLE I

INFORMANT CHARACTERISTIC OF THE STREET SWEEPERS MEDAN IN 2016

\begin{tabular}{llllllll}
\hline No. & Initial & $\begin{array}{l}\text { Distrid } \\
\text { (Code) }\end{array}$ & $\begin{array}{c}\text { Age } \\
\text { (Year) }\end{array}$ & Education & $\begin{array}{c}\text { length of work } \\
\text { (Year) }\end{array}$ & $\begin{array}{c}\text { Working time } \\
\text { (Wib) }\end{array}$ & $\begin{array}{c}\text { workload } \\
\text { (KM) }\end{array}$ \\
\hline 1. & JN & Mai & 35 & SMP & \pm 4 & $13.00-17.00$ & \pm 1 \\
2. & PR & Amp & 33 & SMP & \pm 3 & $13.00-16.00$ & \pm 1.5 \\
3. & SR & Are & 55 & SD & \pm 30 & $06.00-12.00$ & $>2$ \\
4. & DD & Den & 58 & SD & \pm 6 & $06.00-13.00$ & \pm 2 \\
5. & BP & Joh & 57 & SD & \pm 17 & $05.30-12.00$ & \pm 2 \\
6. & SU & Kot & 40 & SD & \pm 20 & $06.00-13.00$ & \pm 2 \\
7. & SH & Pol & 41 & SMP & \pm 5 & $06.00-14.00$ & $>1$ \\
8 & ST & Brt & 48 & SD & \pm 20 & $05.30-13.00$ & \pm 1.5 \\
9. & RS & Bar & 46 & SMP & \pm 3 & $12.00-16.00$ & \pm 1 \\
10. & SA & Hlv & 44 & SMP & \pm 21 & $06.00-12.00$ & $>1$ \\
11. & MG & Pet & 26 & SMP & \pm 2 & $06.00-14.00$ & $>1.25$ \\
12. & AP & Sel & 35 & SMA & \pm 5 & $06.00-14.00$ & $>1$ \\
13. & SG & Sun & 54 & SD & \pm 20 & $05.30-13.00$ & \pm 1.25 \\
14. & NR & Tun & 53 & SMP & \pm 6 & $06.00-13.00$ & \pm 1.5 \\
15. & MI & Bel & 40 & SD & \pm 6 & $06.00-13.00$ & \pm 2 \\
16. & MY & Del & 46 & SMP & 4 & $06.00-12.00$ & \pm 2 \\
17. & SA & Lab & 56 & SD & \pm 18 & $07.00-14.00$ & \pm 2 \\
18. & NU & Mar & 46 & SMP & \pm 4 & $06.00-13.00$ & \pm 1 \\
19. & RO & Tem & 43 & SMP & \pm 3 & $12.30-15.00$ & $>2$ \\
20. & Tr & Tim & 30 & SMA & \pm 4 & $06.00-14.00$ & $>1$ \\
\hline
\end{tabular}

The routine work carried by the informant is sweeping for $\pm 1 \mathrm{~s} / \mathrm{d} \geq 2 \mathrm{~km}$, lifting and attracting the dustbin of rubbish and collecting trash using gloves made of $t$-shirts, while for non routine work, they have to cut the grass, sweep the puddle, and remove the dust. The results of physical hazard sources include abrasions and bruises on the hands caused by a strong hold on the working tools, hot sun and cold in the rainy season; Biological hazards are risks of worm infection caused by collecting garbage using hands or using gloves of jersey material and the risk of contamination of other vectors such as flies, mosquitoes, cockroaches, ants and mice that can cause disease. Chemical hazards which are dust, the smell of

garbage and smoke from the vehicles can cause the risk of respiratory disorders. The psychological hazards are workload and stress caused by the road users and the people are less awareness of littering. Physiological hazard sources are that safety clothing (wear pack) is not comfortable to wear and the sweepers must walk every day for $\pm 1-2 \mathrm{KM}$ and pull the dustbin contains of heavy garbage can potentially cause Musculoskeletal Diasease and for safety hazards are being hit by a motor vehicle, pierced by spikes, needles and former food sticks, chased and beaten by the madman and sexual harassment in the verbal context. The result of the identification of occupational risk is showed in Table 2 as follows: 
TABLE II

RISK ANALYSIS WORK ON STREET SWEEPER MEDAN IN 2016

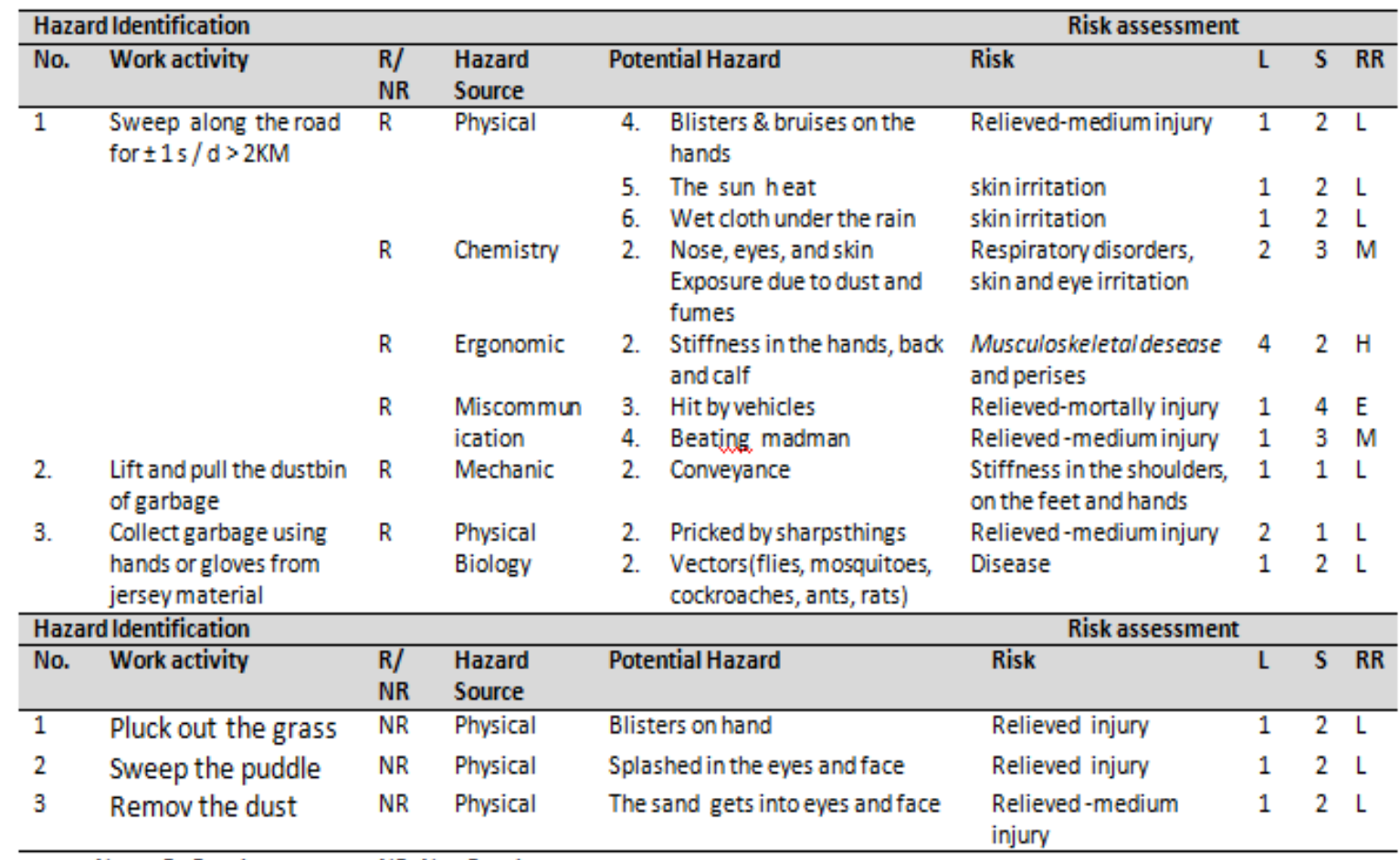

Note: R:Routine $\quad$ NR: Non Routine,

\section{A. Risk Assessment in routine work}

From the three routine-work stages carried out by the street sweepers, it is identified that there are 10 sources of potential hazards and for the results of the risk assessment, there are 6 activities categorized as low (60\%), 2 activities categorized as moderate (20\%), 1 activity categorized as high (10\%), 1 Extreme categorized as activities $(10 \%)$.

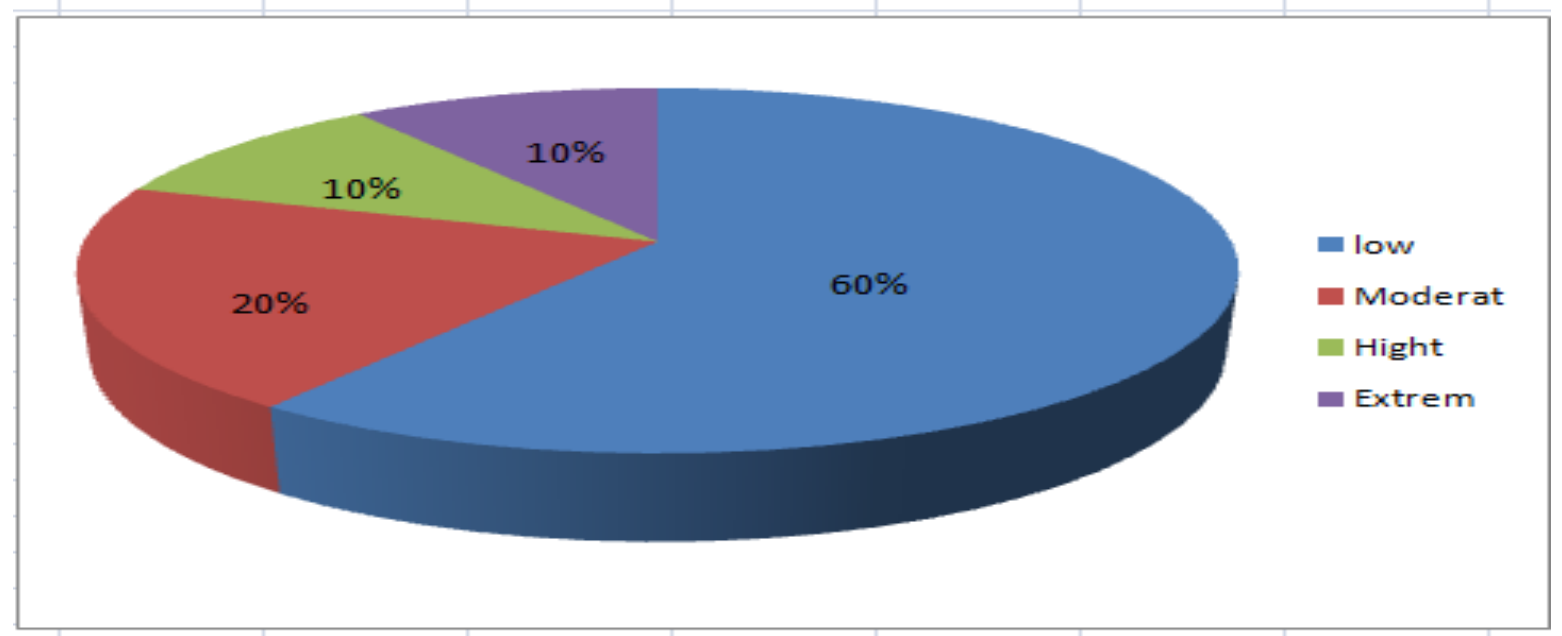

Fig. 1 Percentage of the result risk rating

B. Risk Assessment non routine work

From 3 non-routine work which are grass cutters, puddle sweeper, and dust removals, there are three sources of hazards such as physical harm, which are relievied injury (blisters hands) for manually weed grass, sweep of stagnant water which is relieved injury as a result of the eyes and face exposed by the dirty water, and remove the sand on the side of the road, 
the sand splashed into eyes and face which can cause relieved to moderate injuries. Researchers gave a value of 1 for most likely because there is $\geq 1$ events every year or so and the value 2 for severity, because it can lead to minor injuries and therefore these activities are categorized Low.

\section{CONCLUSION}

Based on the results of the identification of hazard to the street sweepers in Medan which are from the 3 stages of the routine work identified that there are 10 sources of potential hazards and the results of risk assessment, it finds that there are 6 activities categorized as low (60\%), 2 activities categorized as moderate (20\%), 1 activity categorized as high (10\%), 1 activity categorized as Extreme (10\%). And there are three sources of hazards such as physical harm, which are relievied injury (blisters hands) for manually weed grass, sweep of stagnant water which is relieved injury as a result of the eyes and face exposed the dirty water, and remove the sand on the side of the road, the sand into eyes and face which can cause relieved to moderate injury [12].

The results of hazard identification and risk categorized as moderate which is being hit by the madman risk for rilieved-moderate injury and chemical hazards due to dust and fumes risk of causing respiratory problems, eye and skin irritation. A similar thing was found on the research results of S. Smilee Johney at all, in India result prevalence of respiratory symptoms in a street sweeper which are respiratory irritation (50\%), sneezing $(46.6 \%)$, sore throat $(40 \%)$, cough $(36.6 \%), 26.6 \%$ up phlegm and shortness of breath $(23 \%)$

Activities with a high risk category which is for ergonomic hazards which are stiff hands, backs and calf which can cause musculoskeletal desease. According to the research C.O.NKU, at all in Nigeria on 200 workers calabar street sweeper high prevalence of back pain $(40.5 \%$ vs $20 \%$; $\mathrm{P}$ $<0.001)$ [13]. So does the research result of Kanjanar Pintakham and Wattasit Siriwong in Thailand on 75 sweep sweepers, both men and women, it finds that the prevalence result has health problems ergonomically for $89.3 \%$ and privately $80 \%$ physiology hazards.
Extreme activities with risk category is miscommunication with the hazards potential being hit by the vehicle forward and backward with relieved to mortally injury. Those are caused by the absence of roles of work and low understanding of occupational safety and health. According to the research of Ashraful Kabir at all in Bangladesh, it showed that the street sweepers are often exposed to a variety of risk factors fumes, noise, toxic substances and dust particles. They also lack of safety equipment, low effort to safety obtained and low health efforts gained[15].

Work with the source of physical hazards which blisters and bruised hands, hot sun and cold during the rainy season can cause skin irritation, pierced by sharp objects and biological factor which is a disease caused by a vector of diseases such as flies, mosquitoes, cockroaches, ants and mice with the risk level low, Source of Hazards with low risk in the sense that risk is acceptable, making it unnecessary handling / control further. Dinas kebersihan as leading sector street sweeper in Medan is hoped to immediately control, especially for potential hazards with moderate, high and extreme by making and socializing SOP of work so that work well by making $\mathrm{K} 3$ efforts.

\section{ACKNOWLEDGEMENTS}

Thank you for the support provided by the University of North Sumatra, both materially and in material on completion of the study. Research and Development Agency in Medan, Medan City Government Sanitation Department and the entire road Sweeper Melati as informants in this study.

\section{REFERENCES}

[1] BPJS Ketenaga Kerjaan, Angka Kasus Kecelakaan Kerja Menurun, diakses tanggal 1 oktober 2016

http://www.bpjsketenagakerjaan.go.id/berita/2943/Angka-Kasus-

Kecelakaan -Kerja-Menurun.html ; juni 2015

[2] Tarwaka. Dasar- dasar Keselamatan Kerja Serta Pencegahan Kecelakaan Di Tempat Kerja: Surakarta: Harapan Press; 2012.

[3] Ramli, Soehatman. Pedoman Praktis Manajemen Resiko Dalam Perspektif K3 OHS Risk Management: Jakarta: Dian Agung; 2010.

[4] Undang- Undang no 1 tahun 1970, tentang Keselamatan Kerja.

[5] Ramli, Soehatman. Sistem Manajemen Keselamatan dan Kesehatan Kerja OHSAS 18001, Edisi Kedua: Jakarta : Dian Agung; 2010.

[6] M. O. Agwu, The Effects of Risk Assessment (Hirarc) on Organisational Performance in selected Construction Companies in Nigeria diakses tanggal 23 november 2016

http://www.journalrepository.org/media/journals/BJEMT_20/2012/Aug/13 44344373-Agwu_2-3-12BJEMT1317.pdf ; 2012.

[7] [Peraturan Walikota Medan Nomor 14tahun 2014: tentang Pembentukan Unit Pelaksana Teknis Pelayanan Kebersihan Dan Unit Pelaksana Teknis Bank Sampah Pada Dinas Kebersihan Kota Medan

Http://Pemkomedan.go.id/file/14perwal_teknis_pelayanan_kebersihan_dan _teknis_bank_sampah_dinas_kebersihan.pdf; 
[8] Cresswell,J.W. Research Design Pendekatan Kualitatif, Kuantitatif dan Mixed: Yogyakarta: Pustaka Pelajar; 2014.

[9] Sugiyono. Metode Penelitian Bisnis (Pendekatan Kuantitatif, kualitatif, dan R\&D): Bandung: CV Alfabeta; 2012.

[10] Moleong, L.J. Metode Penelitian Kualitatif: Bandung: PT. Remaja Rosdakarya; 2012.

[11] Handbook Risk Management Guidelines Companion To As/Nzs 4360:2004. diakses tanggal 1 Oktober 2016. https://www.google.co.id/search?nfpr=1\&q=Handbook+RISK+MA NAGEMENT+GUIDELINES+Companion+to+AS/NZS+4360:200 $4 \&$ bav $=$ on .2 ,or $\&$ cad $=$ b \&biw $=797 \& b i h=351 \& d p r=1.71 \&$ ech $=1 \& p$ si=-vQ2WKizJ5WavQT11ayQCQ.1479997639384.3\&ei=-

vQ2WKizJ5WavQT11 ayQCQ\&emsg=NCSR\&noj=1; 2005.

[12] Smilee Johncy S., Dhanyakumar G., Vivian Samuel T., Ajay K.T., Suresh Y. Bondade. Acute lung Function Response to Dust in Street Sweeper. (jurnal Elektronik), https://www.ncbi.mlm.nih.gov/pmc/articles/-pdf; Journal DOI:10.7439/ijbr 2013

[13] CO. NKU, E.J.Peters A.I, E shiet, O.OKU, E.E, Osim, Lung Fuction, Oxygen Saturation and Symptoms Among Street Sweepers in Calabar- Nigeria, (Jurnal Elekronik) diakses tanggal 14 September 2016. http: //www.ajol.info/journals.njps; Nigerian Journal Of Physiological Sciences 20 (1-20; 79-84 2005

[14] Kanjanar Pintakham Dan Wattasit Siriwong, Prevalence Rate and Risk Factors Associated With Health Hazards To Select The Magnitude Of Health Problems a Mong Street Sweepers in Chiang Rai Province, Thailand.http://iosrjournals.org/iosr-estft/papers/vol9issue7/Version-2/D09721518.pdf. IOSR -JESTFT Volume 9, Issue 7 Ver. II (July. 2015)

[15] Astraful Kabir, Nadia Farhana, Farzana akter, shahana Jesmin, Ahsan Ali. Sweeping Practices, Perception and Knowledge about Occupational safety and Health Hazard of Street Sweepers in Dhaka City, Bhangladesh: aquality inguiry (jurnal elektronik). http //imsear.li.mahidol.ac.th//bitstream.pdf ; Int J Community Med Public Health. 2015 Aug;2(3):237-243 